\title{
Use of Medicinal Plants Among Thai Ethnic Groups: A Comparison
}

\author{
Methee Phumthum and Henrik Balslev*
}

Section for Ecoinformatics and Biodiversity, Department of Bioscience, Aarhus University, Ny Munkegade 116, DK-8000, Aarhus C, Denmark

*Corresponding author; e-mail: henrik.balslev@bios.au.dk

\begin{abstract}
Use of Medicinal Plants Among Thai Ethnic Groups: A Comparison. Thailand has a large rural population that uses traditional medicinal plants extensively. The country is also the home of many groups of ethnic minorities. But even if much ethnobotanical research has been done in many parts of the country, most studies focused on a single village or a few; only a few of the studies were concerned with comparing the ethnobotanical information among groups or regions of the country. This makes it relevant to compare ethnobotanical knowledge among different ethnic groups in Thailand, including both the rural Thai majority and the various minorities. For our comparison, we collected data about the use of medicinal plants from 64 books, journal articles, scientific reports, and theses published from 1990 to 2014. The data covered 16,789 use reports from 2187 plant species used in 121 villages inhabited by 26 ethnic groups, including rural Thais living in all regions of Thailand. The data were compared using the Informant Consensus Factor (ICF) and clustering analysis. We found that villages inhabited by the same ethnic group often used different plant species while villages in same region had higher similarity of used species for treatments in the same use category, irrespective of which ethnic group that inhabited them. Clustering diagrams showed that similarity in the use of plants was not larger for villages inhabited by the same ethnic groups or from the same regions. So, it appeared that each village had, at least in part, developed its own ethnomedicinal knowledge.
\end{abstract}

\begin{abstract}
ประเทศไทยเป็นประเทศทีประชากรมีความหลากหลายทางชาติพันธ์์ ซึงกลุ่มชาติ พันธุ์ ส่วนใหญ่่มักอาศัยอยู่ในเขตชนบทแ ละมีความรู้เกียวกับการใช้พืชสมุนไพรเพือเป็นยารักษาโรคเป็นอย่างดี ในช่วงหลายปีทีผ่านมา ได้มีรายงานการสำรวจการใช้ประโยชน์ของพืชสมุนไพรขอ งกลุ่มชาติพันธุ์จากหลากหลายพืนที แต่อย่างไรก็ตามพบว่าการสำรวจการใช้ประโยชน์เหล่าน้น มีเพียงส่วนน้อยทีมีการรายงานการเปรียบเทียบองค์ความรู้ด้ านการใช้ประโยชน์พืชสมุนไพรเพือเป็นยารักษาโรคของชาติพันธุ์ต่าง ๆ ฉะน้นการศึกษานีจึงมุ่งเน้นเปรียบเทียบความรู้ด้านการใช้พื้ช สมุนไพรเพือเป็นยารักษาโรคของชาติพันธุ์ต่าง ๆ ในประเทศไทย โดยมีเนื้อหาครอบคลุมถึงการใช้ประโยชน์พืชสมุนไพรของชนพืนเมืองต่าง ๆ อาทิ ชาวเ ขาเผ่าต่าง ๆ ชนเผ่าซาไก มอแกน ชาวผู้ไท รวมถึงกลุ่มประชากรทีอาศัยอยู่ในเขตชนบทได้แก่ กลุ่มชาติพันธุ์ไทย-เขมร กลุ่มอพยพชาวพม่า และชาวไทยพืนเ มือง โดยการศึกษานีได้รวบรวมข้อมูลการใช้ประโยชน์พืชสมุนไพรจากเอกสารต่าง ๆ ได้เก่ รายงานการวิจัย บทความจากวารสารทางวิชาการ หนังสือ และวิทยานิพนธ์ ซึงถูกตีพิมพ์ในระหว่างปี พ.ศ. ๒๕๓๓ - พ.ศ. ๒๕๕๕ จำนวนท้งส้น ๖๕ ฉบับ ประกอบด้วยรายงานย่อยการใช้ประโยชน์จากพืชสมุน ไพรกว่า ๑b, $0 \circ \circ$ คร้ง จากพืชสมุนไพรท้งสีนกว่า ๒ าคของประเทศไทย จากเปรียบเทียบองค์ความรู้ด้านการใช้พืชสมุนไพรของกลุ่มชาติพันธุ์เหล่านีโดยอาศัยดัชนี Informant Consensus Factor (ICF) และการวิเคราะห์การจัดกลุ่ม (cluster analysis) พบว่ามีความแตกต่างขององค์ความรู้ด้านการใช้ประ โชชน์พืชสมุนไพรเพือเป็นยารักษา โรคจากหมู่บ้านต่าง ๆ ภายในกลุ่มชาติพันธ์เดียวกัน ในขณะทีผลการเปรียบเทียบองค์ความรู้ด้านการใช้ประโยชน์พืชสมุนไพรของหมู่บ้านต่าง ๆ ในเขตภู มิภาคเดียวกันชืให้เห็นว่าการใช้องค์ความรู้้านการใช้ประ โยชน์จ ากพืชสมุนไพรในภูมิภาคเดียวกันมีความคล้ายคลึงกันมากกว่า ในส่วนของผลการวิเคราะห์ก ารจัดกลุ่มโดยใช้องค์ความรู้ด้านการใช้ประโยชน์จากพืชสม นไพรเป็นเกณฑ์ พบว่า หมู่บ้านต่าง ๆ จากชนเผ่าเดียวกัน หรือหมู่บ้านต่าง ๆ ในภูมิภาคเดียวกัน ไม่ได้ถูกจัดให้อยู่ในกลุ่มเดียวกันทังหมด จึงสรุปได้ว่าแต่ละหมู่บ้านในประเทศไทยมีองค์ความรู้เฉพาะด้านการใช้ประโยชน์พืชสมุนไพรเพือ เป็นยารักษาโรคเป็นของตนเอง.
\end{abstract}

Key Words: Comparative ethnobotany, Thai hill tribes, Thai rural population.

\footnotetext{
${ }^{1}$ Received 16 March 2018; accepted 11 October 2018; published online 3 December 2018
}

Submitted 16 March 2018; Accepted 15 August 2018.

Electronic supplementary material The online version of this article (https://doi.org/10.1007/s12231-018$9428-0)$ contains supplementary material, which is available to authorized users.

\section{Introduction}

Studies of traditional knowledge from many parts of the world have shown that traditional medicinal plant selection is driven by both cultural and ecological factors. Focus has been mostly on cultural and historical drivers (Bennett 1992; Bernstein et al. 1997; Gruca et al. 2014; Joshi and Edington 1990; 
Junsongduang et al. 2014), but in many cases, ecology and availability also influence which plants are used (Gaoue et al. 2017). In Nepal, for instance, Chaubas and Syabru are two communities that used plant resources from different environments (evergreen oak forest and Himalayan blue pine forest) and had corresponding differences in medicinal plants used (Joshi and Edington 1990). In the Amazon, the Shuar's use of an amazing diversity of traditional medicinal plants depended on the very rich rainforest flora and, at the same time, the uses were governed by cultural traditions that involved many ritual elements (Bennett 1992). In some cases, different populations of the same ethnic group, which were separated from each other for centuries, maintain similar patterns of plant uses (Inta et al. 2008).

As with most other biological and sociological phenomena, traditional use of medicinal plants is uneven with some medicinal species being commonly used and others being used more rarely. In a previous study, we distinguished between medicinal plants with only one use-report, i.e., species that were mentioned in the literature a single time, and other plants with two or more use-reports, which we called "commonly used species" (Phumthum et al. 2018). Our assumption is this: species with two or more independent reports of being used as medicine are much more likely to be effective in traditional treatments. In contrast, species with a single use-report may truly represent very rare but still effective uses, or they may originate as mistakes on behalf of the informants or researcher. Therefore, it may be useful, when comparing traditional uses of medicinal plants, to separate commonly used species from all medicinally used species.

Thailand is blessed with over 30 ethnic minorities (Hidayati et al. 2015) that belong to five language families: Austronesian, Hmong-Mien, SinoTibetan, Tai-Kadai, and Austro-Asiatic (SAC Database 2016; also see the Electronic Supplementary Material [ESM] found in Appendix 1). Among these ethnic minorities, 10 groups have been recognized as so-called hill tribes living in remote areas in the mountains of Thailand (IWGIA 2010). Many villages, where these people now live, rely on wild natural resources, especially plants for food and medicine (Anderson 1993; Inta et al. 2008). The current Thai hill tribes represent both original Thai ethnicities and, to a very high degree, migrants from neighboring regions in Myanmar, China, Vietnam, and Laos (Anderson 1993). These migrations occurred over the past few hundred years and have created a kaleidoscopic mixture of cultural diversity in northern Thailand (Tribal Research Institute 1995). Their current traditional knowledge comes in part from the culture practiced in the original homelands and in part from the ecological conditions and the flora and fauna that their new homelands in northern Thailand provide. Over the past decades, several villages have had their traditional knowledge of medicinal plants documented, especially among the hill tribes in northern Thailand (Anderson 1993). But only a few studies have addressed the combined cultural and ecological drivers of traditional plant use. A study of the Akha, in both their original homeland in China and in villages of migrant populations in Thailand, found that although those populations were separated over 100 years ago, they still have similar patterns of plant uses. However, because they currently live under different ecological conditions, the Chinese and the Thai Akha use different species for the same purposes (Inta et al. 2008). Karen and Lawa, who live in adjacent villages within the same habitat and with the same forest resources in the Chiang Mai province of Thailand, used different species of medicinal plants for the same purposes (Junsongduang et al. 2014). However, these studies only reported results from a few villages and a couple of ethnic groups in Thailand, so we cannot conclude that people in the same ethnic group use similar plants and that they are different from other ethnic groups. These examples prompted the hypothesis we explore here; namely, that people who live in different villages but belong to the same ethnic group would have a high degree of similarity in the medicinal species they used and that villages inhabited by different ethnic groups would have a lower degree of similarity in the species they used. Here, we focus on those ethnic groups that have had their traditional knowledge of medicinal plants well documented in ethnobotanical studies. We also make a distinction between all used species and commonly used species. Our aim was to compare medicinally used plant species of (1) villages inhabited by same ethnic group in all regions and (2) all villages inhabited by all ethnic groups in the same region.

\section{Methods}

\section{ETHNOMEDICINAL DATA}

Reports of medicinal uses of plant species were extracted from 64 published papers, theses, 
books, and reports produced in the period 1990-2014 (see Appendix 2, Electronic Supplementary Material [ESM]. Each use of a medicinal plant for a specific purpose by a particular group in a particular village was counted as a use-report. All use-reports were traced back to the original source, and repeated mentions of the use in subsequent publications were not counted as new use-reports. Only records of medicinal plants for which the original publication gave a scientific name were included (see Appendix 2, ESM). The data from these references provided 16,789 medicinal usereports for 2187 plant species in 206 families (Phumthum et al. 2018). Our survey does not pretend to cover all ethnomedicinal studies in Thailand, but we consider it to be representative due to its wide geographic coverage of 121 villages distributed throughout the country. Each single usereport was classified in use categories following a standard (Cook 1995). In our analysis, we made a distinction between all used species and species with more than two records in the literature (commonly used species).

\section{ETHNIC GROUPS}

Ethnic group names used here are the same as those used in the original references. In cases when the original references did not provide a name for an ethnic group, they were referred to "rural Thai people," which we divided into seven groups according to floristic regions used in Thai Plant Names (Pooma and Suddee 2014). The data include one village inhabited by recently migrated Burmese people. Of the 121 villages represented in the data, 21 were Karen, 14 were rural Thai in southern Thailand, and 13 were Hmong. The remaining 23 ethnic groups were all represented by seven or fewer villages in our database (Fig. 1).

\section{Floristic Regions}

To test the similarity of used species from villages in the same region, all villages mentioned in the references were divided into seven groups corresponding to the floristic regions used in Thai Plant Names (Pooma and Suddee 2014). Based on differences in vegetation, these regions are believed to have different floristic compositions, which means that villages in the same region would have a more similar set of plants compared to villages in different floristic regions. The northern region is covered in dry-deciduous forests, dry-hill forests, and montane temperate forests and includes IndoBurmese floristic elements. The northeastern region has dry-deciduous to mixed-deciduous forests, and in some small areas dry-evergreen forest or savanna mostly with floristic elements from south China, but also a few Indo-Chinese elements. The eastern region is covered in dry-dipterocarp forests and savannas with the influence of central and southern Indo-Chinese elements. The southwestern region includes the so-called Tenasserim or Lower Burmese flora; bamboo forests are common, but evergreen forests, mixed-deciduous forests, and mangroves can also be found. The central region is the main rice cultivating area and only has a few remnants of the original forest and mangroves that are still found along the coasts. The southeastern region has a mixture of Indo-Chinese and Malesian floristic elements, including dipterocarps and species of Lophopetalum and Parkia. The peninsular region is covered by dipterocarp rain forests, mangroves, and swamps. Welzen et al. (2011) proposed a simpler system-based on analyses of databases containing distribution data of species - with only four floristic or phytogeographical regions. We have maintained the seven-region system because it coincides with some linguistic dialects; for example, the northern I-San dialect is spoken in the northeastern region and the southern I-San dialect spoken in the eastern region, and the central and southwestern regions also have different Thai dialects.

\section{INFORMANT CONSENSUS FACTOR}

The use of medicinal plant species within each category, following the Economic Botany Data Collection Standard (Cook 1995), was tested for homogeneity using the Informant Consensus Factor (ICF) (Trotter and Logan 1986):

$\mathrm{ICF}=\frac{N u r-N t}{N u r-1}$

where Nur is the number of use reports in a particular category and $N t$ refers to the number of species that were used as medicine in that particular category. ICF values close to one (1) imply that there was a well-defined selection of the plants for medicinal use or that there had been exchanges of information between informants. ICF values close to zero (0) suggest that plants were selected randomly for medicinal use or that there had not been 


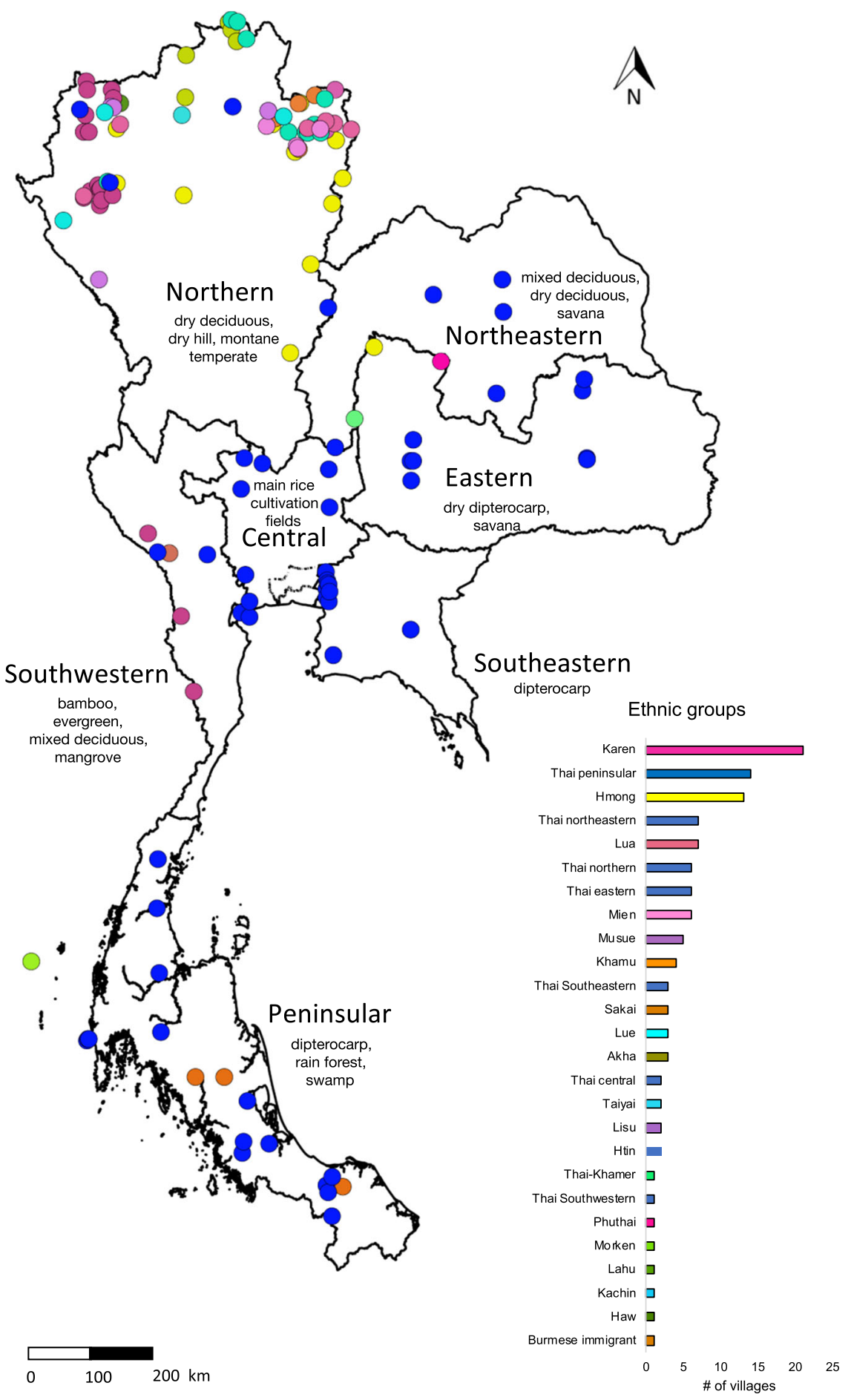

Fig. 1.. Locations of 121 villages color coded for each of the 26 ethnic groups (19 ethnic minority groups and 7 rural Thai people with blue color from all seven regions). The data originated from 64 references published from 1990 to 2014. 
any exchange of knowledge between the informants (Gazzaneo et al. 2005; Srithi et al. 2009).

In this analysis, we tested similarity of used medicinal plants from all villages inhabited by the same ethnic groups. We also tested similarities between villages inhabited by different ethnic groups located in the same region. We excluded ethnic groups that were represented in only a single village because, in such cases, we could not compare similarity within a particular group. After excluding groups according to these criteria, we had 19 ethnic groups for village comparisons. However, for similarity of villages within each of the seven regions, the data from all 26 ethnic groups were analyzed.

\section{Cluster Analyses}

All villages were grouped based on their medicinal species. We created matrices of species for all use categories from all villages. Each matrix had villages as column names and species as rows. A cell was given the value one (1) when there was at least one use of a particular species in a particular village or zero (0) for lack of information about the use of that species in that village. The analysis was done by using complete linkage cluster analysis in the $\mathrm{R}$ package (R Core Team 2014).

To cluster villages based on medicinally used species may not be enough to inform about similarity in traditional knowledge of medicinal plants because the same plant species may be used to treat different health conditions in different villages. To avoid this bias, all villages were clustered again based on species in each of the medicinal use categories following Cook (1995). To remove biased results from uncommon uses in some categories, this analysis involved only the following categories: digestive system disorders, infections/infestations, nutritional disorders, genitourinary system disorders, muscular-skeleton system disorders, and injuries. All these categories had high numbers of reported uses (Phumthum et al. 2018).

\section{Results}

\section{INFORMANT CONSENSUS FACTOR}

Eastern Thai people, Lua, Khmu, northeastern Thai people, and Karen had high ICF values in several categories. Mien, Hmong, peninsular, and northern Thai people had moderate ICF values in many categories. Taiyai, H'tin, southwestern Thai people, Lue, and southeastern Thai people, in contrast, had very low ICF values in almost all categories, mostly close to or equal to zero (0). A few use categories in some ethnic groups had values higher than 0.5. Usage of plants to treat circulatory system disorders among the Khmu and to treat $a b$ normalities among the northeastern Thai people had ICFs that were higher than 0.6 (Fig. 2a).

Comparing ICF based on use categories by regions contrasted to the comparison by ethnic groups (Fig. 2a, b). The difference between the ethnic groups' ICFs (lower) and those for the regions (higher) is mostly due to the different levels of analysis. Most ICF values for regions were higher than 0.5 , especially in the northern region where they were higher than $0.5 \mathrm{ICF}$ in all categories. The values from the peninsular region were also high except for the category nervous system disorders. Many categories from the northeastern and eastern regions had high ICF values, while there were low ICF values in many categories from the southwestern, southeastern, and central regions (Fig. 2b).

There were high ICF values for digestive system disorders, infections/infestations, and respiratory system disorders in many ethnic groups, whereas ICF values for plants used for mental disorders and inflammation were very low in almost every ethnic group (Fig. 2a). For the set of values for regions, there were no outstanding values across all regions. Almost all categories showed high values except the categories of mental disorders, inflammation, and abnormalities (Fig. 2b).

\section{Cluster Analyses}

Our analysis showed that some villages clustered according to ethnic or linguistic groups. Some Hmong $(\mathrm{Hm})$ and Mien (Ya) villages that belonged to the Hmong-Mien language family were in the same large group in the cluster diagram. Rural Thai villagers (Th) in the eastern region (E) were clustered together in one group. Karen $(\mathrm{Kr})$ villages from the northern region $(\mathrm{N})$ were split into two groups. All Sakai (Sk) villages were together in one branch. In addition, there were pairs of villages from the same ethnic groups that were very close to each other. However, more than half the villages were scattered along the tree without showing any pattern, for example, Lua (Lw), Akha (Ak), and rural Thai people (Th) in each region, as well as many Hmong villages (Fig. 3).

Clustering of individual medicinal use categories were different from clustering that included all 
a Ethnic groups
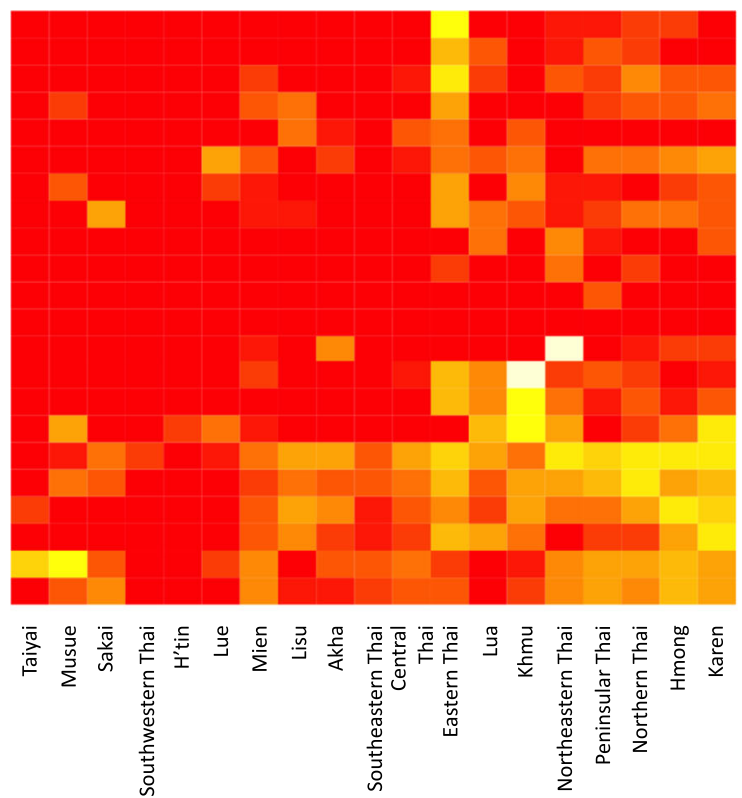

b Regions

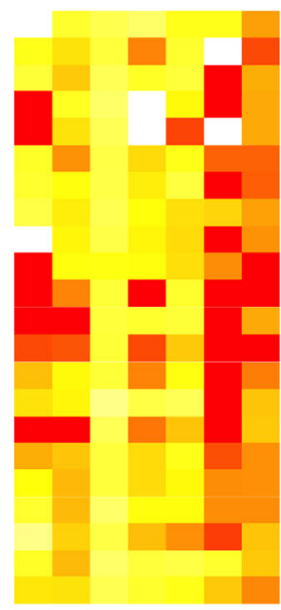

Metabolic system disorders Endocrine system disorders Skin/subcutaneous tissue disorders Pregnancy system disorders Nervous system disorders Injuries Pain Poisonings III-defined disorders Neoplasms

Mental disorders Inflamation Abnormalities Circulatory system disorders Sensory system disorders Blood system disorders Digestive system disorders Infections/infestations Genitourinary system disorders Muscular-skeletal system disorders Respiratory system disorders Nutritional system disorders

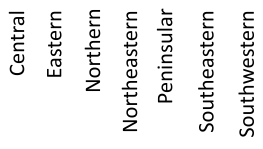

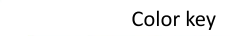

Fig. 2.. Informant consensus factors (ICFs) calculated for each of 19 ethnic groups (a) and for all data from 121 villages in seven regions (b) based on 64 references published from 1990 to 2014 . Red color corresponds to low ICF value while the whiter color corresponds to high ICF values (see scale in lower right corner). Cells in the same column represent ICFs obtained for each of the ethnic groups or regions distributed over the use categories (rows). Cells in the same rows present ICFs for a particular use category distributed over the ethnic groups.

categories of medicinal uses. Each diagram had its unique village relationship clustering. There was only one group of five Karen villages that were closely clustered in all analyses. Hmong and Mien villages, which were clustered in Fig. 3, were divided into small groups and appeared in different positions in each of the diagrams showing specific use categories. Three Sakai villages were never clustered but appeared in different branches in each diagram. Many pairs of villages, from the "all used species" diagram, were not clustered in several of the diagrams for individual medicinal use categories. There were only few pairs of villages that were paired in a few categories such as Hmong village (Hm_N_08 and Hm_N_10), local Thai People in eastern region (Th_E_03 and Th_E_04), Mien (Ya_N_03 and Ya_N_04), and Karen (Kr_N_06 and Kr_N_07) (see Appendix 3, ESM; Figures A1-A6).

The regions of the villages showed similar results to the classification by ethnic group. Many clusters included villages from different floristic regions, for example, a cluster of villages in the peninsular, southwestern, and central areas (Th_P_25, Kr_SW_2, Th_P_28, Th_P_27, and Th_C_02), or a sub-cluster including many villages in the north, peninsular, northeast, east, and southwest (MS_N_04, MS_N_03, Th_P_22, Th_NE_01, Li_N_01, Hm_N_07, Mk_P_01, Th_E_06, Ht_N_02, Lw_N_02, Hm_N_01, MB_SW_01, and Ch_N_01) (Fig. 4). This pattern was repeated for cluster diagrams for specific medicinal use categories (see Figures A1-A6 in Appendix 3, ESM).

\section{Ethnic Groups, Regions, AND Commonly USED SPECIES}

The regression models showed that there was a relationship between the numbers of studied villages and the numbers of medicinal plants (Fig. 4a). With more studied villages, there was a higher number of all as well as the number of commonly used medicinal species (species with $>2$ records in the data) (Fig. 4b).

\section{Discussion}

To secure the quality of the data for this metaanalysis, we were selective and only included 


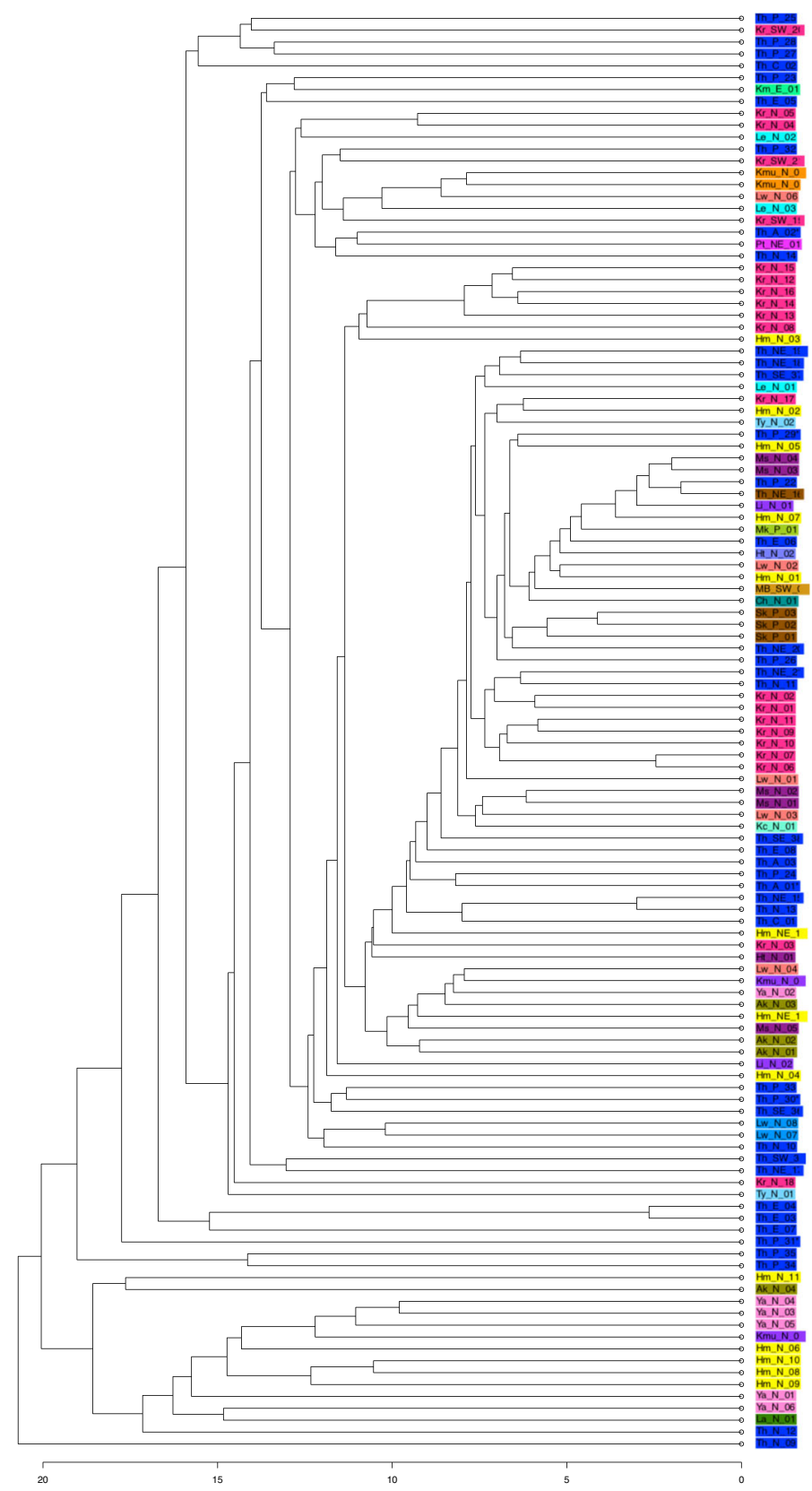

Fig. 3.. Village cluster diagram, based on used medicinal plant species among 26 ethnic groups living in 121 villages for which data were obtained in a meta-analysis of ethnomedicinal patterns in Thailand based on 64 references published from 1990 to 2014. To analyze the similarity of medicinal plants, each village was assigned a unique code following the formula: EE_A(A)_XX where EE is an abbreviation of an ethnic group name detailed in Fig. 4. A(A) represents the villages' floristic regions (Pooma and Suddee 2014) and XX is the order of the village in an ethnic group $(01,02,03, \ldots)$. The first two digits indicate the tribal names of each village $(\mathrm{Th}=$ local Thai people, $\mathrm{La}=\mathrm{Lahu}, \mathrm{Ya}=\mathrm{Mien}, \mathrm{Hm}=$ Hmong, Kmu $=$ Khmu, Ak = Akha, Ty= Taiyai, Kr = Karen, Lw = Lawa, Li $=$ Lisu, Ms. = Lahu, Ht = H'tin, Kc = Khachin, $\mathrm{Sk}=$ Sakai, $\mathrm{Ch}=\mathrm{Haw}, \mathrm{MB}=$ Recent migrated Burmese, Mk = Morkan, Le $=$ Tai Lue, Km $=$ Thai - Khamer, and $\mathrm{Pt}=$ Phuthai), while the next letter(s) represent village regions $(\mathrm{N}=$ north, $\mathrm{NE}=$ northeast, $\mathrm{E}=$ east, $\mathrm{C}=$ center, $\mathrm{SW}=$ southwest, $\mathrm{SE}=$ southeast, and $\mathrm{P}=$ Peninsular). The use of the same color means the same ethnic group. 
a Ethnic groups

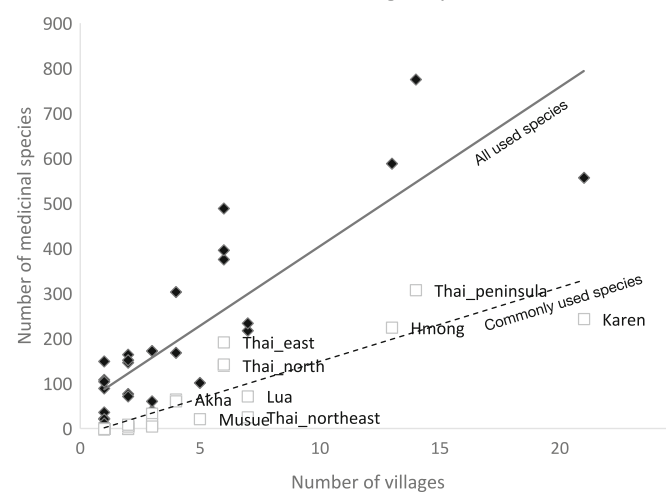

b Regions

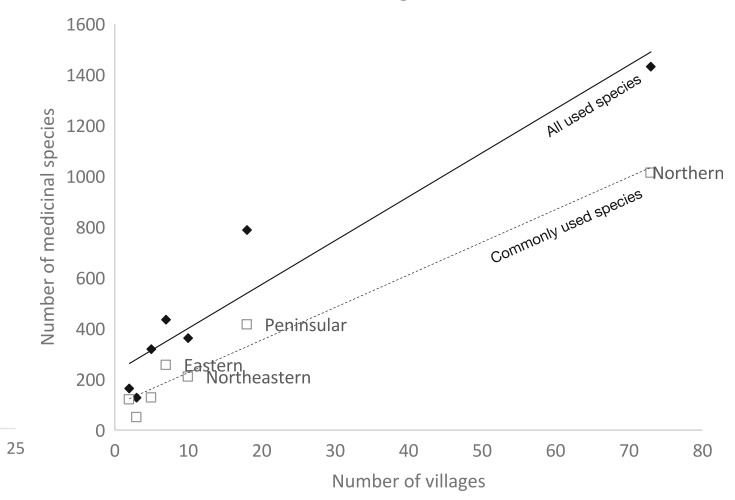

Fig. 4.. The relationship between the number of studied villages and the number of medicinal species reported for each ethnic group (a) and each region (b). Black-diamonds are all used species in each ethnic group and white squares represent numbers of commonly used species in a specific ethnic group. The solid line is the regression of number of all medicinal used species; the dashed line is the regression of commonly used medicinal species.

references that met certain standards; for example, mentioned plants were documented with their scientific names. And, although there may be variation in the protocol followed in the 64 cited references, they were all similar in that the information was derived by interviews that solicited information about specific uses of specific species, and that the names should be so well documented that their scientific names were known. Still, even if the cited studies were the best ones available concerning Thai medicinal plants, we could not be sure that the lists of species used in each village were exhaustive. Species could be missing on the lists because they were not available in the village at the time of collecting the data, or because the researcher may have had limitations in terms of time or other resources. Other data that could have strengthened our meta-analysis would have been on the total floristic list for each village so it could be determined whether a lack of use was due to the unavailability of a species or whether it was due to other causes. Such data, however, are extremely rare in ethnobotanical studies, and therefore not available for metaanalysis like this one. We do feel that the lists of medicinal plants that have been available to us from each of the 121 villages are representative and that they make a valid basis for comparisons of the villages and their used species. On the other hand, our previous study showed that the 2187 reported medicinal plant species in Thailand did not represent saturation on the species/village curve, so additional medicinal species are to be expected in Thailand (Phumthum et al. 2018).
The Informant Consensus Factor (ICF) values for uses of medicinal plants among ethnic groups and rural Thai people were high in these categories: digestive system disorders, infections/infestations, genitourinary system disorders, muscular-skeleton system disorders, respiratory system disorders, injuries, and nutritional system disorders (Fig. 2a, b). These high ICFs show that the studied villages in Thailand shared traditional knowledge of medicinal plants to cure symptoms related to these use categories (Gazzaneo et al. 2005; Srithi et al. 2009). Thus, similar species of plants were used cross-culturally throughout Thailand in these medicinal use categories.

Focusing on the ICFs of specific ethnic groups, most values in the various use categories were equal to or close to zero. This suggests that people from the same ethnic group who live in different villages used different plant species to treat ailments in the same categories. This was contrary to the comparison of used species by floristic regions, which suggested that the villages of a region, regardless of which ethnic group they were inhabited by, used similar species for treatments in the same use categories (Fig. 2a, b). As a floristic region represents similar plant communities in that particular area, it is possible that availability of plants was one of the factors influencing selection of medicinal species in Thailand.

The cluster analysis for villages based on medicinally used species suggested that each village had unique traditional knowledge of medicinal plants. The diagrams showed clustering that was unrelated 
to either language families or ethnic groups. Moreover, each village (except a few Karen villages) were found in different branches of the diagrams when individual medicinal use categories were analyzed separately (Fig. 3). That showed that people from different villages had different sets of known medicinal plants.

Some groups (Karen, Hmong, northern Thai people, peninsular Thai people, northeastern Thai people, Khamu, Lua, and eastern Thai people) used similar sets of medicinal plants in several categories with relatively high ICF values. Nevertheless, most of those high ICF values were not higher than 0.5 (Fig. 2a), possibly because we were faced with a limitation of data sources. Some ethnic groups, such as Karen, have been intensively studied because they are the largest group of ethnic minorities in Thailand while H'tin and Sakai had fewer studies due to their small population. The differences in the numbers of studied villages in each floristic region were affected by the variety of ethnic groups in each region. The northern Thailand region is rich in ethnic groups and cultures, so it had many studied villages. On the other hand, the central region, in which most of the population is rural Thai people, had very few studies. We could not control this sampling size bias.

We made plot graphs to look for any relationship between the number of all used species and commonly used species by the ethnic groups and regions. The higher the number of studied villages for an ethnic group, the higher were both the number of all used and commonly used species. Karen, Thai people in the peninsular region, and Hmong had relatively high numbers of all used species as well as commonly used species since more studies had been made of these ethnic groups. In contrast, other groups with fewer studied villages had lower numbers of both all used species and commonly used species (Fig. 4a). This pattern also appeared in the relationship between the number of studied villages and the numbers of medicinal species (both for all used species and for commonly used species). The northern region, which had the most studied villages (73 villages), had the highest numbers of both all used species and commonly used species. Peninsular, eastern, and northeastern regions, which had 10 to 20 studied villages, had much fewer used species compared to the northern region, but there were more used species and commonly used species than in other regions that had less than 10 studied villages (Fig. 4b).
Our anticipation that with more studied villages, both all used species and commonly used species would increase was confirmed (Fig. 4a). Even though we have data for 2187 species from 121 villages, the accumulation curve did not reach a saturation point for all medicinal species in Thailand. A more complete list of medicinal plants in Thailand would require the study of more villages. The saturation level for the number of commonly used species was at approximately 1250 species, which was reached with 80 studied villages (Phumthum et al. 2018). Our assumption that when more villages were studied, similarities of traditionally used species overlapped by chance seemed to be supported by a study from two communities in Nepal that used plants from different forest types (evergreen-oak forest and Himalayan blue pine forest) that provided different sets of medicinal plants (Joshi and Edington 1990). On the other hand, the Amazonian Shuar were somewhat similar to other Amazonian communities in Ecuador, Bolivia, Peru, and Venezuela, possibly because there is a high level of exchange of traditional knowledge about medicinal plants throughout the region (Bennett 1992). One driver for selecting species for medicinal use is the ease of access to the plants (Bennett and Husby 2008; Martin 1995). Therefore, widespread and locally common plant species have a high probability of being selected as medicines by people in many villages.

Our results agreed with those found in a comparison of medicinal plant knowledge in villages inhabited by the Akha living in Thailand and China, respectively. These Akha communities in Thailand and China, which were separated over 100 years ago, had major differences in medicinally used species, but they shared use-patterns, such as plant families used, plant growth forms, and habitats of medicinal plants (Inta et al. 2008). Our results also agreed with the study of medicinal plant uses of Karen and Lawa in Chiang Mai, Thailand. These two neighboring villages, belonging to different ethnic groups, shared the same natural resources in the surroundings of their villages, but still, they had only few shared medicinal species. Moreover, modes of preparation and applications were significantly different in these two villages and these different patterns were interpreted as being driven by their different historical and cultural backgrounds (Junsongduang et al. 2014). However, since there was no comparison between different villages of the same tribe in that study, it might be 
that different use patterns of these two villages were also driven by development of new knowledge after migration apart from their historical and cultural backgrounds.

Here, we show that each village has its own traditional knowledge of medicinal plants and we suggest that it may have developed independently in each village. Therefore, traditional knowledge from all these villages in Thailand should be conserved and protected. Although we found that villages had developed new "traditional knowledge" on medicinal plants, it is unfortunate that ancient knowledge from their original places has disappeared after settlement as demonstrated by the low similarities of used species in each tribe in our analysis. Many modern medicines were developed from ethnomedicinal templates (Cox 2000; Cox and Balick 1994; Lewis 2003), so vanishing traditional knowledge will reduce opportunities to discover new effective drugs in the future. It is true that even though some traditional knowledge has disappeared, our results also suggested that people have developed new knowledge after settlement in different environments in new areas. However, using plants in different ways in the same ethnic group may imply that most knowledge of their ancestors had been forgotten. The ethnobotanical study of Akha, who have been separated for over 100 years, showed that even though those communities used the same plants in similar ways and the same plants in family level, some uses of plants at the species level were different (Inta et al. 2008). This implies that uses of plants in isolated communities changes through times. A recent study found that many traditional uses of palms in Ecuador were no longer practiced after a 30-year period (Schneider et al. 2017). Our study raises even more concern because villages from the same ethnic groups were isolated from each other after settlement in Thailand over a period of centuries. We do not know how much knowledge has been lost. Moreover, the use of medicinal plants depends on natural resources. Now we face a period of vast biodiversity loss (Barnosky et al. 2011; Cardinale et al. 2012). This means that development of traditional knowledge from fewer remaining plant species may not be able to compensate for the loss of knowledge from more abundant species. Besides, we are also facing a period of fast traditional knowledge erosion driven by globalization, climate change, and urbanization (Bussmann and Sharon 2006; Ragupathy et al. 2008; Srithi et al. 2009; Voeks and Leony 2004).
In general, traditional knowledge was transmitted from generation to generation orally and through daily life activities (Anyinam 1995; Kaval et al. 2014). Sometimes, traditional knowledge disappeared without transmission before traditional healers passed away (Cox 2000; Giday et al. 2003; Ji et al. 2004). Before this valuable knowledge disappears, the young generations in each village must document and publish it for future use. In addition, our results suggest that each village had its own traditional knowledge on medicinal plants, which was different from that of other villages although the villages were inhabited by the same group. Therefore, we encourage ethnobotanists to visit and document ethnobotanical knowledge in as many villages as possible to conserve traditional knowledge.

\section{Conclusion and Perspectives}

People in the same floristic region had higher similarities of plant species used for medicines compared to the similarity of plant uses by people in the same ethnic group. This suggests that the availability of plant species was one of the factors that influence the selection of medicinal plants in Thailand. However, because the similarity was not very high, this was not a main factor for plant selection. We also found that each village had its own and unique ethnomedicinal knowledge, even though they were villages in the same floristic region, such as H'tin, Taiyai, or Lue. Many ethnic groups that migrated to Thailand some centuries ago have different uses of plants for medicines nowadays. After isolation and settlement in new areas, people who are recognized as members of the same ethnic group but live in different villages use plants in different ways. This suggested that they had developed their own new knowledge and forgotten the original knowledge they had before they were isolated from each other. For knowledge conservation, this teaches us as ethnobotanists to work harder to fight the rapid erosion of traditional knowledge. The result from this study demonstrates that we need to document ethnomedicinal knowledge in as many individual villages as we can. It does not matter if we repeat a study of the same ethnic group that has been studied before, as long as the village is new to ethnomedicinal study. Since many plants that were formerly used as traditional medicines today provide modern drugs, some documented ethnomedicinal plants can become templates for pharmaceutical development in the future. Many people who 
possess traditional knowledge live in remote areas far away from public health centers. Most people from the older generations never had basic education (see the list of references in Appendix 2, ESM). Consequently, they cannot themselves write down their knowledge to transfer it to the younger generations. The traditional way of knowledge transfer was by telling or by sharing routine activities. Sometimes informants passed away before their knowledge was shared. Therefore, ethnobotanical studies are needed to carry on documentation of medicinal knowledge. This could protect the lives of villagers from general illness and may also save many people in our world through new drug discoveries. We suggest that ethnobotanical knowledge should be documented from all villages and ethnic groups as soon as possible and made available to the communities. Local schools should become involved with local healers to provide integrated learning to children in the communities. Local governments should promote uses of traditional medicines. Medicinal plants should be propagated and cultivated in agricultural areas or home gardens.

\section{Acknowledgements}

MP thanks the Development and Promotion of Science and Technology Talents Project (DPST) and the Thai Government for a stipend to study at the Aarhus University Graduate School for Science and Technology (GSST). HB thanks the Carlsberg Foundation for support of his studies of Thai flora (grant \#CF14-0245). We thank all ethnobotanists who worked very hard in these decades who provided invaluable sources of data for our analyses.

Open Access This article is distributed under the terms of the Creative Commons Attribution 4.0 International License (ht t p:/ / creativecommons.org/licenses/by/4.0/), which permits unrestricted use, distribution, and reproduction in any medium, provided you give appropriate credit to the original author(s) and the source, provide a link to the Creative Commons license, and indicate if changes were made.

\section{Literature Cited}

Anderson. 1993. Plants and people of the golden triangle: Ethnobotany of the hill tribes of northern Thailand. Portland, Oregon: Dioscorides Press.
Anyinam, C. 1995. Ecology and ethnomedicine: Exploring links between current environmental crisis and indigenous medical practices. Social Science \& Medicine 40(3):321-329.

Barnosky, A. D., N. Matzke, S. Tomiya, G. O. U. Wogan, B. Swartz, T. B. Quental, C. Marshall, J. L. McGuire, E. L. Lindsey, K. C. Maguire, B. Mersey, and E. A. Ferrer. 2011. Has the Earth's sixth mass extinction already arrived? Nature 471(7336):51-57.

Bennett, B. C. 1992. Plants and people of the Amazonian rainforests. BioScience 42(8):599-607.

- and C. E. Husby. 2008. Patterns of medicinal plant use: An examination of the Ecuadorian Shuar medicinal flora using contingency table and binomial analyses. Journal of Ethnopharmacology 116(3):422-430.

Bernstein, J. H., R. Ellen, and B. B. Antaran. 1997. The use of plot surveys for the study of ethnobotanical knowledge: A Brunei Dusun example. Journal of Ethnobiology 17(1):69-96.

Bussmann, R. W. and D. Sharon. 2006. Traditional medicinal plant use in Loja province, Southern Ecuador. Journal of Ethnobiology and Ethnomedicine 2(1):44.

Cardinale, B. J., J. E. Duffy, A. Gonzalez, D. U. Hooper, C. Perrings, P. Venail, A. Narwani, G. M. Mace, D. Tilman, D. A. Wardle, A. P. Kinzig, G. C. Daily, M. Loreau, J. B. Grace, A. Larigauderie, D. S. Srivastava, and S. Naeem. 2012. Biodiversity loss and its impact on humanity. Nature 486(7401):59-67.

Cook, F. E. M. 1995. Economic botany data collection standard: Prepared for the international working group on taxonomic databases for plant sciences (TDWG). London Borough of Richmond upon Thames, London. London: Royal Botanic Gardens, Kew.

Cox, P. A. 2000. Will tribal knowledge survive the millennium? Science 287(5450):44-45.

- and M.J. Balick. 1994. The ethnobotanical approach to drug discovery. Scientific American (June):60-65

Gaoue, O. G., M. A.Coe, M. Bond, G. Hart, B. C. Seyler, and H. McMillen. 2017. Theories and major hypotheses in ethnobotany. Economic Botany 71(3):269-287.

Gazzaneo, L.R.S., R.F.P. de Lucena, and U.P. de Albuquerque. 2005. Knowledge and use of medicinal plants by local specialists in a region of Atlantic Forest in the state of Pernambuco (Northeastern Brazil). Journal of Ethnobiology and Ethnomedicine 1(9) 
Giday, M., Z. Asfaw, T. Elmqvist, and Z. Woldu. 2003. An ethnobotanical study of medicinal plants used by the Zay people in Ethiopia. Journal of Ethnopharmacology 85(1):43-52.

Gruca, M., T. R. Van Andel, and H. Balslev. 2014. Ritual uses of palms in traditional medicine in sub-Saharan Africa: A review. Journal of Ethnobiology and Ethnomedicine 10:60.

Hidayati, S., F. M. Franco, and R. W. Bussmann. 2015. Ready for phase 5-Current status of ethnobiology in Southeast Asia. Journal of Ethnobiology and Ethnomedicine 11:17.

Inta, A., P. Shengji, H. Balslev, P. Wangpakapattanawong, and C. Trisonthi. 2008. A comparative study on medicinal plants used in Akha's traditional medicine in China and Thailand, cultural coherence or ecological divergence? Journal of Ethnopharmacology 116(3):508-517.

IWGIA. 2010. Who we are: Indigenous peoples in Asia. International Work Group for Indigenous Affairs (IWGIA). Chiang Mai: IWGIA Briefings.

Ji, H., P. Shengji, and L. Chunlin. 2004. An ethnobotanical study of medicinal plants used by the Lisu people in Nujiang, northwest Yunnan, China. Economic Botany 58:253-264.

Joshi, A. R. and J. M. Edington. 1990. The use of medicinal plants by two village communities in the Central Development Region of Nepal. Economic Botany 44(1):71-83.

Junsongduang, A., H. Balslev, A. Inta, A. Jampeetong, and P. Wangpakapattanawong. 2014. Karen and Lawa medicinal plant use: Uniformity or ethnic divergence? Journal of Ethnopharmacology 151(1):517-527.

Kaval, I., L. Behçet, and U. Cakilcioglu. 2014. Ethnobotanical study on medicinal plants in Geçitli and its surrounding (Hakkari-Turkey). Journal of Ethnopharmacology 155(1):171-184.

Lewis, W. H. 2003. Pharmaceutical discoveries based on ethnomedicinal plants: 1985 to 2000 and beyond. Economic Botany 57(1):126-134.

Martin, J. M. 1995. Ethnobotany: A methods manual. London: Chapman \& Hall.

Phumthum, M., K. Srithi, A. Inta, A. Jusnongduang, K. Tangitman, W. Pongamornkul, S. Trisonthi, and H. Balslev. 2018. Ethnomedicinal plant diversity in Thailand. Journal of Ethnopharmacology 214:90-98.
Pooma, R. and S. Suddee. 2014. Tem Smitinand's Thai Plant Names, revised edition. Bangkok: The Office of the Forest Herbarium, Department of National Parks, Wildlife and Plant Conservation.

R Core Team. 2014. R: A language and environment for statistical computing. Vienna: R Foundation for Statistical Computing. http://www.Rproject.org/. (15 January 2016)

Ragupathy, S., N. G. Steven, M. Maruthakkutti, B. Velusamy, and M. M. Ul-Huda. 2008. Consensus of the "Malasars" traditional aboriginal knowledge of medicinal plants in the Velliangiri holy hills, India. Journal of Ethnobiology and Ethnomedicine 4(1):8.

SAC Database. 2016. Ethnic groups in Thailand. Bankok: Princess Maha Chakri Sirindhorn Anthropology Centre (SAC).

Schneider, E., R. Cámara-Leret, A. Barfod, and C. S. Weckerle. 2017. Palm use by two Chachi communities in Ecuador: A 30-year reappraisal. Economic Botany 71(4):342-360.

Srithi, K., H. Balslev, P. Wangpakapattanawong, P. Srisanga, and C. Trisonthi. 2009. Medicinal plant knowledge and its erosion among the Mien (Yao) in northern Thailand. Journal of Ethnopharmacology 123(2):335-342.

Tribal Research Institute 1995. The Hilltribes of Thailand, 4th. Chiang Mai: Tribal Research Institute.

Trotter, R. T. and M. H. Logan. 1986. Informant consensus: A new approach for identifying potentially effective medicinal plants. In: Plants in indigenous medicine and diet: Biobehavioral approaches, ed., N. L. Etkin, 91-112. Bedford Hills: Redgrave Publishing Company

Voeks, R. A. and A. Leony. 2004. Forgetting the forest: Assessing medicinal plant erosion in eastern Brazil. Economic Botany 58(1):S294-S306.

Welzen, P. C., A. Madern, N. Raes, J. A. N. Parnell, C. Byrne, T. Curtis, J. Macklin, A. Trias Blasi, A. Prajaksood, D. Simpson, P. Bygrave, S. Dransfield, D. Kirkup, J. Moat, P. Wilkin, C. Couch, P. Boyce, K. Chayamarit, P. Chantaranothai, and A. Teerawatananon. 2011. The current and future status of floristic provinces in Thailand. In: Land use, climate change and biodiversity modeling: Perspectives and applications, eds., Y. Trisurat, R. P. Shrestha, and R. Alkemade, 219-247. Hershey: IGI Global 